\title{
Headwaters Deforestation for Cattle Pastures in the Andes of Colombia and Its Implications for Soils Properties and Hydrological Dynamic
}

\author{
Guillermo Vásquez-Velásquez \\ Forest Science Department, National University of Colombia, Medellín, Colombia \\ Email: glvasque@unal.edu.co
}

How to cite this paper: Vásquez-Velásquez, G. (2016) Headwaters Deforestation for Cattle Pastures in the Andes of Colombia and Its Implications for Soils Properties and Hydrological Dynamic. Open Journal of Forestry, 6, 337-347.

http://dx.doi.org/10.4236/ojf.2016.65027

Received: June 24, 2016

Accepted: August 28, 2016

Published: August 31, 2016

Copyright $\odot 2016$ by author and Scientific Research Publishing Inc. This work is licensed under the Creative Commons Attribution International License (CC BY 4.0).

http://creativecommons.org/licenses/by/4.0/ (c) (i) Open Access

\begin{abstract}
Deforestation of headwater in the Andes of Colombia is a historical process that has its origins in pre-Hispanic communities and in nineteenth and twentieth centuries, intensified by settlers and farmers. These lands have been intended mainly to pasture cattle. Soil compaction, caused by the trampling of cattle, was evaluated in soils derived from volcanic ash (Andisols), with reference to values found for variables in undisturbed natural forests in the same region. The compared parameters were bulk density $(D b)$, total porosity $(\alpha)$, soil resistance to penetration $(R p)$ and pore size distribution, analyzed by water retention curves (WRC). The grazed soils had significant differences with respect to the natural forest reference values: $D b$ was $53.7 \%$ higher, $\alpha$ was reduced by $11.0 \%$ and $R p$ in the first $7.5 \mathrm{~cm}$ of the top soil was more than double, with an average increase of 275.2 to $527.2 \mathrm{kPa}$. The analysis indicated that compacted soils had relatively uniform reduction in distribution of macro, meso and micropores. It was concluded that deforestation followed by pasture land destination in steep headwaters generates significant compaction processes that can affect the infiltration, percolation and soil water storage, which would have important hydrological implications: augmentation of surface runoff and soil erosion, decreased the base flow and increased direct runoff. For this reasons, it is considered that forest restoration of headwaters is important for the maintenance of hydrological functions of large river systems.
\end{abstract}

\section{Keywords}

Forest Influences, Deforestation, Soil Compaction, Headwaters

\section{Introduction}

Soils intensively used in agriculture, livestock and forestry practices tend to be altered 
due to the action of loads exerted on the surface, which compress the soil and result in loss of the pore space; this phenomenon is known as "compaction" and, depending on the magnitude, frequency and source of the load, may severely or slightly affect the bulk density, total porosity and pore size distribution. It is an environmental problem of the first order not only due to the extent of compacted soils in the world, some 68 million hectares, but also because identification is often complex because the symptoms are not very visible (Hamza \& Anderson, 2005; Herbin et al., 2011). Compaction causes undesirable damage given the impact on several hydrodynamic functions, such as soil water flow and solute transport, water retention, changes in the saturated and unsaturated hydraulic conductivity, reduction in the infiltration capacity and limitations for the development of root systems (Alaoui et al., 2011).

The headwaters in the upper part of the large and medium water systems in the Andes of Colombia, with nearly two million hectares, have been deforested to a large extent, giving way to various forms of agriculture and grazing; another lands have been established with commercial forest plantations after some decades of grazing use (Figure 1). Since the area is sensitive in terms of the hydrological functioning of the large watersheds, which provide the water supply for many populations, industries and hydroelectric projects, changes in land use affect the soils in several ways, particularly through compaction, and therefore affect the hydrological response.

This research was aimed at determining the levels of compaction of volcanic soils (Andisols) caused by the trampling of cattle, which has been used for decades in the headwaters of the Andes in Colombia, with reference values found in equivalent areas with undisturbed natural forest conditions.

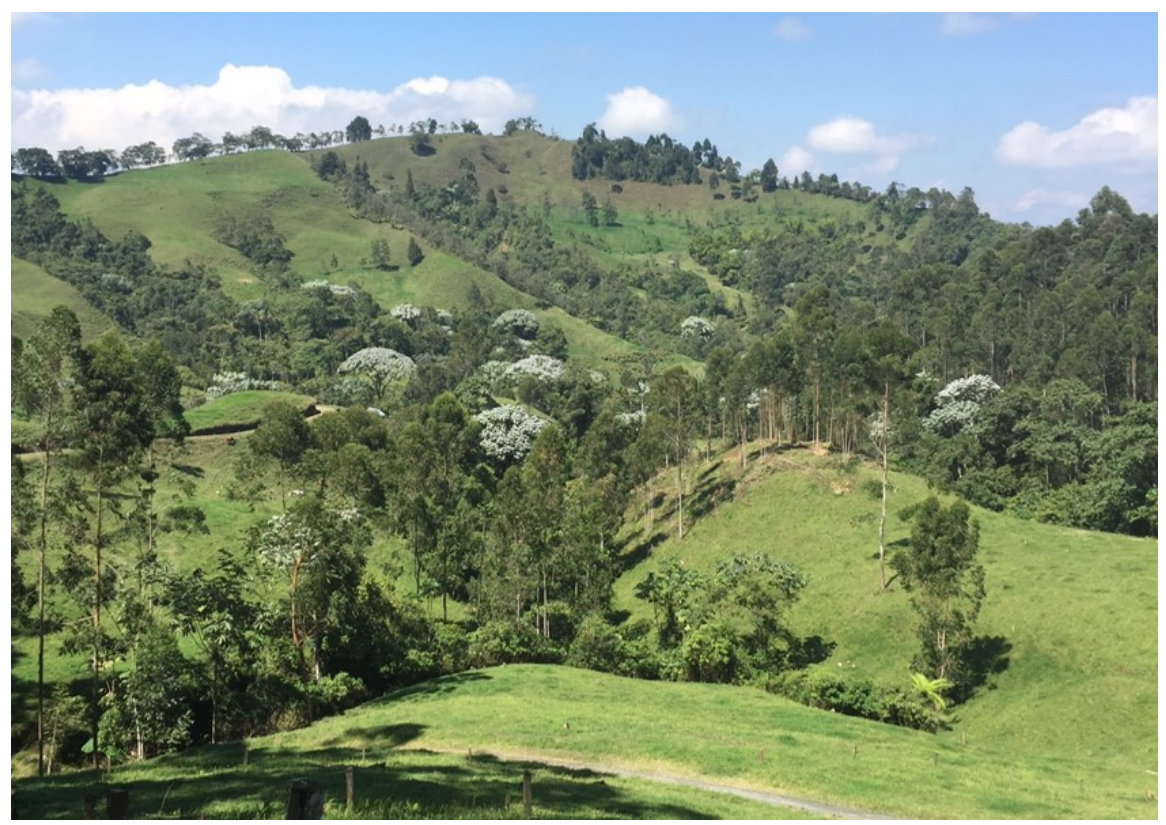

Figure 1. Deforested areas in headwaters for cattle pastures in Central Andes of Colombia. Commercial forests of Pinus and Eucalyptus species are frequently planted in old areas intensively grazing for some decades. 


\section{Materials and Methods}

Two representative areas were selected in the Central Andes of Colombia, in a rural area of the municipality of Santa Rosa de Cabal, Department of Risaralda, intertropical region at $4^{\circ} 50^{\prime} \mathrm{N}$ latitude and $75^{\circ} 34^{\prime} \mathrm{W}$ longitude; average altitude $1980 \mathrm{~m}$; annual precipitation $2680 \mathrm{~mm}$; and little variation in temperature, with an average of $17.1^{\circ} \mathrm{C}$. The first area is an unaltered mountain native forest (BN), and second area is an extensive cattle pastures (PA) established about eight decades ago on deforested land. These study units were close together $(3.5 \mathrm{~km})$, on the same slope, between $50 \%$ and $75 \%$, at the same altitude (aprox. $2000 \mathrm{~m}$ ) and recent volcanic soils (Andisols), deep (+) 120 $\mathrm{cm}$, slightly acidic $(\mathrm{pH}<6.5)$, with $20 \%-30 \%$ organic matter contents.

In the two headwaters the following indicator variables for the degree of compaction were used: bulk density $(D b)$, total porosity $(\alpha)$, pore size distribution, by interpreting water retention curves (WRC), and soil resistance to penetration $(R p)$. For the determination of $D b, \alpha$ and $R p, 32$ randomly selected sampling sites were selected in the top $10 \mathrm{~cm}$ of mineral soil, excluding the layer of litter. Soil samples were taken with a 99.1 $\mathrm{cm}^{3}$ metal cylinder $(V s)$. The labeled samples were weighed on an analytical balance to obtain the wet weight $(P S)$. In the laboratory, the samples were dried in an oven at $104^{\circ} \mathrm{C}$ and were weighed daily until obtaining a constant weight (dry weight, Vs).

The $D b$ was determined with the following equation:

$$
D a=\frac{P s}{V s}
$$

In order to calculate the total porosity ( $\alpha$ ), the density value of the particles $D p=2.42$ $\mathrm{g} / \mathrm{cm}^{3}$ was used, found by Hincapié (2011) for Andisols in the same region:

$$
\alpha=\left(1-\frac{D a}{D p}\right) * 100=\left(1-\frac{D a}{2.42}\right) * 100
$$

The WRC were prepared using the determinations in the laboratory for the content of gravimetric moisture ( $u$ in $\mathrm{g} / \mathrm{g}$ ) at pressures of 0.0/0.1/0.3/3.0/5.0/15.0 bar, using the pressure-plate apparatus. The results of the determinations were transformed to the volumetric moisture content $(\theta)$ using the bulk density $(D b)$ found for the undisturbed samples taken at the same sites. The general model of the water retention in the soil is expressed as (Seki, 2007):

$$
\theta(h)=\left[\theta_{r}+\left(\theta_{s}-\theta_{r}\right)\right] * S_{e}
$$

where:

$\theta(h)$ : Volumetric moisture content as a function of pressure $(h)$.

$\theta_{r}:$ Residual moisture content.

$\theta_{s}$ : Saturation moisture content.

$S_{e}$ : Effective saturation (normalized, $S_{e}=\theta / \theta_{s}$ ).

The pedotransfer model proposed by van Genuchten (1980) was used to determine the Se parameters:

$$
S_{e}=\left[\frac{1}{1+(\alpha h)^{n}}\right]^{m}
$$


where the $\alpha$ and $n$ are van Genuchten parameters and $m=1-(1 / n)$.

Because estimating the model parameters, as well as $\theta_{r}$ and $\theta_{s}$, is inherently nonlinear, the computer program RETC ver. 6.02/2009 was used, based on numerical methods of nonlinear parameter estimation (Van Genuchten et al., 1991). The pore size distribution from the WRC was obtained from the theory of capillary (Leij et al., 2002), which states that radius $r$ of the pores depends on the surface tension of the water, $T$, and the repose angle of the water contact in the meniscus formed in the pore, $\varphi$ :

$$
r=2 T \cos \varphi / h
$$

For the $R p$ determinations, a digital penetrograph Fiel Scout SC- $900^{\circ}$, with a $45 \mathrm{~cm}$ stem extension and $1 / 2$ inch diameter cone and $45^{\circ}$ angle was used. This device registers to logger data readings every $2.5 \mathrm{~cm}$ in $\mathrm{kPa}$; the penetration depth is controlled by an ultrasonic transmitter-receiver. Since $R p$ is a function of the soil water content, being higher with low moisture contents (high matrix potential) and low with moisture contents that are close to saturation (Wolkowski \& Lowery, 2008; Vaz et al., 2013), readings were made in the range of soil moisture more widespread in the study area, which, given the high capacity of water retention in Andisols and the high rainfall and uniform intra-annual distribution, were between $40 \%$ and $60 \%\left(0.4\right.$ to $\left.0.6 \mathrm{~cm}^{3} / \mathrm{cm}^{3}\right) . \theta$ was controlled in the field by direct readings with the TDR device (Time Domain Reflectometer), Hobo Onset $10 \mathrm{HS}^{\bullet}$; the values were subsequently verified in the laboratory.

The data obtained for each basin were examined for normal distribution using the Shapiro-Wilk test, and the Grubbs test or "studentized extremes test" was used to determine the existence of outliers. Later, the data were subjected to analysis of variance (ANOVA, Statgraphics Centurion XV.I).

\section{Results and Discussion}

\subsection{Bulk Density $(D b)$ and Total Porosity $(\alpha)$}

Table 1 shows the principal statistics found for the sample series of $D b$ and $\alpha$ in each headwater. The analysis of variance for the mean $D b$ presented significant differences

Table 1. Statistics for the bulk density $(D b)$ and total porosity $(\alpha)(\mathrm{n}=32)$.

\begin{tabular}{|c|c|c|c|}
\hline Statistics & Natural Forest(BN) & Pasture(PA) & Sig. \\
\hline \multicolumn{4}{|c|}{ Bulk Density ( $D a)$} \\
\hline Mean $\left(\mathrm{g} / \mathrm{cm}^{3}\right)$ & 0.41 & 0.63 & ${ }^{* *}$ \\
\hline Range $\left(\mathrm{g} / \mathrm{cm}^{3}\right)$ & $0.13-0.72$ & $0.44-0.84$ & \\
\hline Standard Dev. $\left(\mathrm{g} / \mathrm{cm}^{3}\right)$ & 0.14 & 0.10 & \\
\hline CV (\%) & 34.11 & 16.54 & \\
\hline \multicolumn{4}{|c|}{ Total Porosity $(\alpha)$} \\
\hline Mean (\%) & 83.1 & 74.0 & ${ }^{* *}$ \\
\hline Range (\%) & $70.4-94.6$ & $65.2-81.8$ & \\
\hline Standard Dev. (\%) & 5.8 & 4.3 & \\
\hline $\mathrm{CV}(\%)$ & 6.9 & 5.8 & \\
\hline
\end{tabular}

Note: ${ }^{*} P<0.01$ 
between the groups $(P<0.001)$. The $\mathrm{BN}$ had a lower mean $D b$ value than the PA soil; this indicates that there was an increase in the soil mass per volume unit and thus a decrease in the pore space where there were compacting loads due to trampling by cattle. The increase in the $D b$ of the grazed soils was $53.7 \%$, as compared to the reference value found for the BN. As such, in the pastures, the total porosity decreased $11.0 \%$.

While a significant increase in the $D b$ was seen in the grazed soils, the mean and range remained in the field of universally reported values for Andisols, less than 0.9 $\mathrm{g} / \mathrm{cm}^{3}$, which also occurred for the total porosity ( $\alpha$ ), which was high to very high for both conditions (Shoji et al., 1993; Nanzyo, 2002; Tobón et al., 2010; Hincapié, 2011).

The CV for the $D b$ in $\mathrm{BN}$ was high due to widely changing conditions in the forest ecosystem that were related to the microtopography, accumulation of litter and differential erosion of the ground. Since it was relatively low in PA, it is interpreted as a generalized condition of compaction in all of the pastures because the compacting loads generated by cattle were distributed throughout the area.

Reports from other studies have led to the broad conclusion that almost any agricultural activity involving permanent or temporary land use, change in land use, or incorporation of technological treatments for the establishment, management and harvest of crops, tend to generate compacting loads that increase the bulk density and decrease the pore space. In the Colombian Amazon piedmont and using clay soils and different physiographic positions, Pinzón \& Amézquita (1991) found a significant increase in $D b$ because of grazing cattle. In the Amazonian foothills of Caquetá, Colombia, with high rainfall and soils with varying degrees of degradation due to grazing cattle, Jiménez et al. (2012) found significant differences in the $D b$ when increasing the degree of degradation of the pastures. Gómez (2011) in Andisols on the Sabana de Bogotá plains, showed that tasks performed with tractors were a significant cause for an increase in the $D b$. Similar conclusions were reached by Vzzotto et al. (2000) in clay soils in southern Brazil, where the trampling of cattle caused a significant increase in the bulk density in the first $5 \mathrm{~cm}$ of the soils, which remained for at least six months. On the flooded pampas of Argentina, Taboada \& Lavado (1988) found slight increases in the $D b$ caused by grazing. In the tropical lowlands of Perú, Alegre \& Lara (1991) found a significant increase of between 0.21 and $0.35 \mathrm{~g} / \mathrm{cm}^{3}$ in overgrazed areas, as compared to soils in a natural forest. In the Lar River valley, Iran, with a semiarid temperate climate, a concentrated rainy season, and sandy soils and limestone, Chaichi et al. (2005) found significant increases in $D b$ during the rainy season when sheep grazing was intensified.

Since the compaction of soils and consequent loss of pore space is closely related to water dynamics in soil (infiltration, storage and percolation processes), it is possible to say that under the studied pasture conditions (PA), there were greater limitations for the recovery and flow of water with respect to the original conditions of the soils before they were altered $(\mathrm{BN})$. As a whole, the headwaters linked to the medium and large watersheds will have lower water soil recharge, rapid generation of surface and subsurface runoff, and lower or slower generation of base flows. The impulse-response function derived from the rainfall-runoff process, is therefore an acceleration factor that may 
become important in hydrographic systems given the significant extension of the areas with those conditions in the Central Andes of Colombia: high rate of deforestation for the development of extensive cattle pastures.

\subsection{Pore Size Distribution}

Table 2 contains the values of the saturation moisture content $(\theta s)$ and residual moisture content $(\theta r)$ estimated with the van Genuchten function to obtain the WRC; Figure 2 has the respective curves. Although no statistical differences were found for the

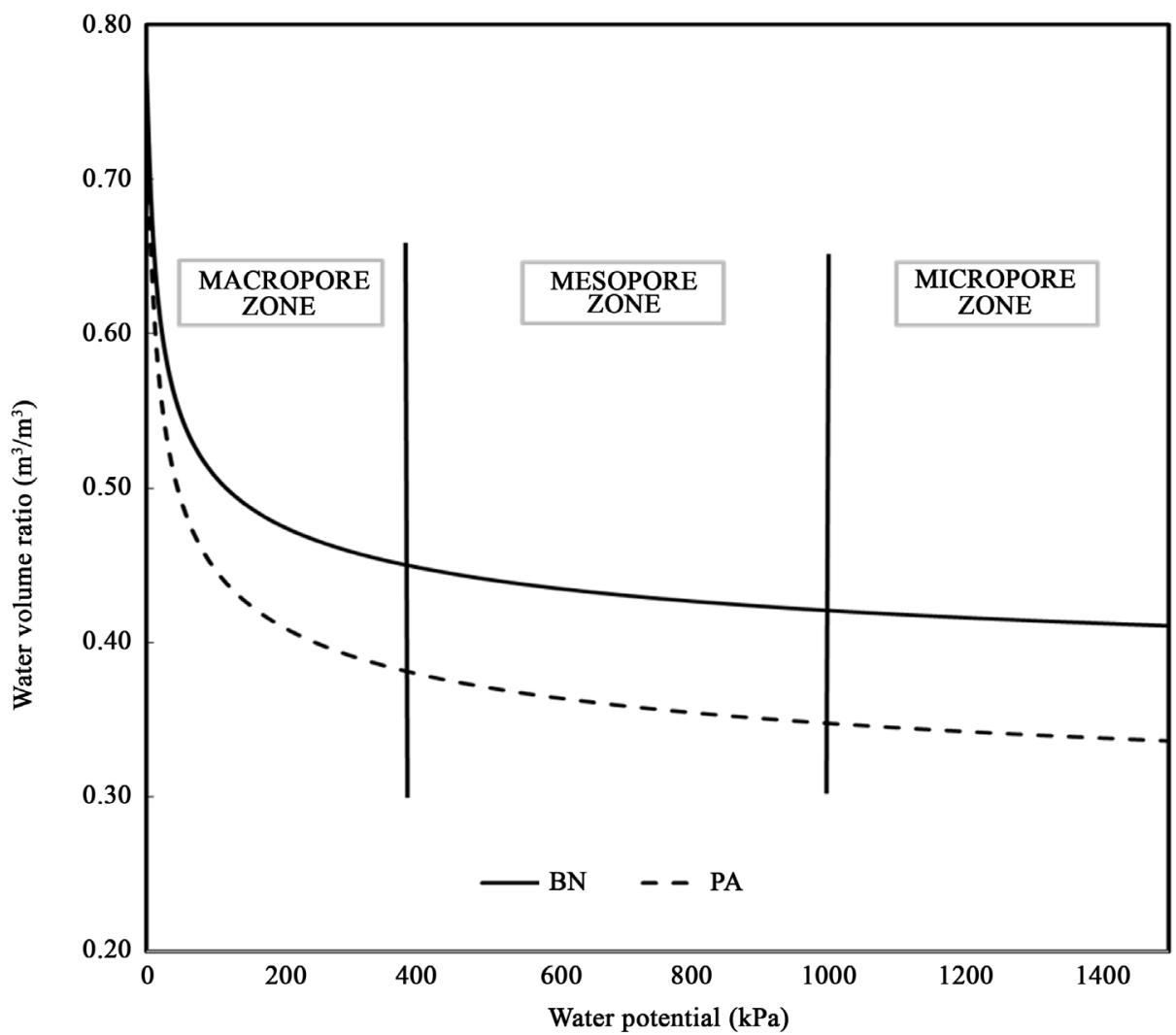

Figure 2. Water retention curves (WRC) for soils in Natural Forest (BN) and Pastures (PA) indicating the zones of porosity defined in Table 2.

Table 2. Estimated parameters for the van Genuchtenpedo transfer function and distribution percentage by pore size in the Natural Forest (BN) and Pastures (PA).

\begin{tabular}{ccc}
\hline Parameter & BN & PA \\
\hline Saturation moisture $\left(\theta_{s}\right)\left(\mathrm{m}^{3} / \mathrm{m}^{3}\right)$ & 0.768 & 0.747 \\
Residual moisture $\left(\theta_{r}\right)\left(\mathrm{m}^{3} / \mathrm{m}^{3}\right)$ & 0.336 & 0.251 \\
Coefficient of determination $\left(\mathrm{R}^{2}\right)$ & 0.98 & 0.99 \\
\hline Porosity and Distribution Percentage & BN & PA \\
\hline Macropores (diameter $>75 \mu \mathrm{m}$ and pressure $<390 \mathrm{kPa})$ & 45.9 & 48.6 \\
Mesopores (diameter $30-75 \mu \mathrm{m}$ and pressure $390-1000 \mathrm{kPa})$ & 3.6 & 4.1 \\
Micropores (diameter $<30 \mu \mathrm{m}$ and pressure $>1000 \mathrm{kPa})$ & 50.5 & 47.3
\end{tabular}


WRC, the BN had higher water contents for all of the examined pressures than the PA. This result is concurrent with the findings for the bulk density and total porosity: soils of $\mathrm{BN}$, in its natural state, are undisturbed, with little erosion and high contents of organic matter, which is why, it is composed of high proportions of macro, meso and micropores; instead, in PA the soil that had less total porosity, as was determined in the previous section, and, as discussed in this research, was attributed to the effect of compaction caused by cattle.

When considering the water available to plants (WAP), defined as the water content between the field capacity (FC) at a pressure of $33 \mathrm{kPa}$ and the wilting point (WP) at $1500 \mathrm{kPa}$ (Reichardt \& Timm, 2004), it is verified that, in both WRC, this value was approximately $0.20 \mathrm{~m}^{3} / \mathrm{m}^{3}$, but the minimum and maximum thresholds were higher in the BN than in the PA. However, Tobón et al. (2010) argued that the limit value of FC= $33 \mathrm{kPa}$ may not be appropriate for Andisols given the high water storage capacity due to the amorphous all ophanic clays, making a limit of FC at $10 \mathrm{kPa}$ more suitable; when calculating with this value, an WAP of about $0.30 \mathrm{~m}^{3} / \mathrm{m}^{3}$ for the three conditions was obtained.

Hincapié (2011) indicated that the mineralogical composition of Andisols, essentially allophane, imogolite and aloisita, defines both a high capacity for water retention, micro and mesoporosity, and a high residual moisture content $\theta r$ at pressures (negatively) over $1500 \mathrm{kPa}$. The estimations of $\theta r$ in the van Genuchten model (Table 2) yielded values exceeding $0.35 \mathrm{~m}^{3} / \mathrm{m}^{3}$ for $\mathrm{BN}$ and higher than 0.25 for PA. In similar soils of the Central Andes, this author found residual moisture for the first horizon in agriculture soils higher than $0.25 \mathrm{~m}^{3} / \mathrm{m}^{3}$, and saturations higher than $0.60 \mathrm{~m}^{3} / \mathrm{m}^{3}$, which corresponds with the findings of this investigation.

According to Soil Survey Staff pore size classification (SSS, 2008) and the theory of capillarity and its relationship with the pressure of water in soils (Leij et al., 2002), the zones of porosity were defined as shown in Figure 2 and listed in Table 2. For all of the pressures and for the three regions of defined porosity, there was a uniform difference in the moisture retention, about $0.8 \mathrm{~m}^{3} / \mathrm{m}^{3}$ between $\mathrm{BN}$ and PA. This indicates that the effect of porosity loss caused by compaction was verified, which was approximately proportionally in all of the pore sizes. However, a slight increase in the percentage of macropores was seen in PA, along with a slight decrease of micropores in $\mathrm{BN}$; this could be an indication that compaction by trampling occurs at high moisture contents, as seen in the study region, characterized by a high and evenly distributed rainfall, which affects the micropores more intensely. Other researchers (Hamza \& Anderson, 2005; Tobón et al., 2010; Alaoui et al., 2011; Dorner et al., 2012) have reported on the fundamental effect of macropores.

\subsection{Soil Resistance to Penetration $(R p)$}

Table 3 shows the statistics for the determination of $R p$, carried out at six depths and for the average of the soils in $\mathrm{BN}$ and PA. The mean values are shown in Figure 3. The lower resistance to penetration found in $\mathrm{BN}$ (reference value) was consistent with the 


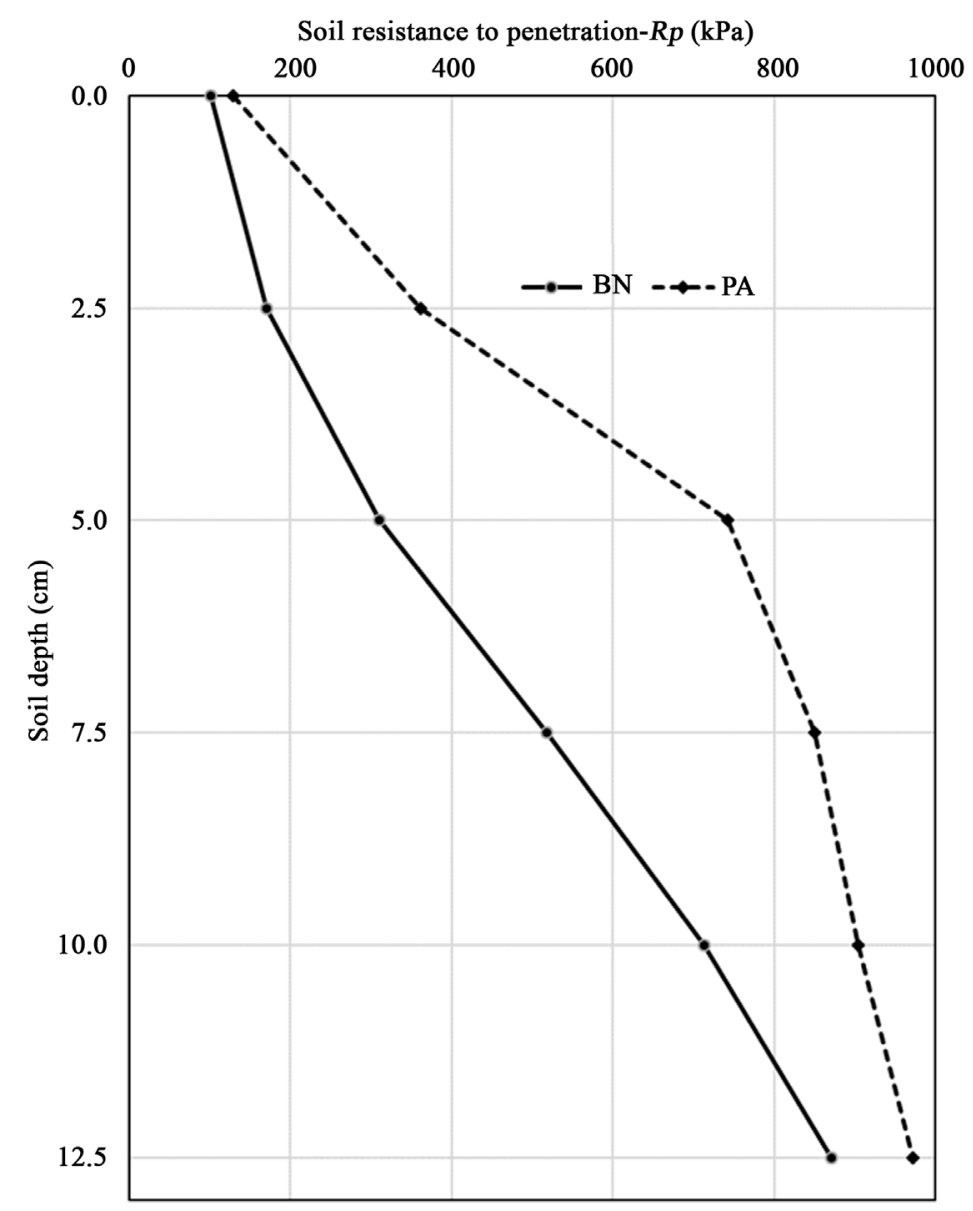

Figure 3. The $R p$ at six depths in the soils of $\mathrm{BN}$ and PA.

Table 3. Statistics for the determination of $R p$ at six depths in soils of BN and PA.

\begin{tabular}{cccccccc}
\hline \multirow{2}{*}{$\begin{array}{c}\text { Depth } \\
(\mathrm{cm})\end{array}$} & \multicolumn{3}{c}{ Natural Forest (BN) } & \multicolumn{3}{c}{ Pasture (PA) } & Sig. \\
\cline { 2 - 7 } & $X_{R p}(\mathrm{kPa})$ & $S_{R p}(\mathrm{kPa})$ & $\mathrm{CV}_{R p}(\%)$ & $X_{R p}(\mathrm{kPa})$ & $S_{R p}(\mathrm{kPa})$ & $\mathrm{CV}_{R p}(\%)$ & \\
\hline $\mathbf{0 . 0}$ & 101.9 & 88.9 & 87.2 & 128.3 & 110.2 & 85.9 & n.s. \\
2.5 & 170.4 & 173.3 & 101.7 & 361.1 & 175.8 & 48.7 & $*$ \\
$\mathbf{5 . 0}$ & 310.3 & 219.3 & 70.7 & 742.1 & 228.4 & 30.8 & $*$ \\
7.5 & 518.1 & 279.9 & 54.0 & 851.2 & 234.6 & 27.6 & $*$ \\
10.0 & 713.2 & 243.3 & 34.1 & 904.0 & 249.7 & 27.6 & $*$ \\
12.5 & 870.9 & 259.6 & 29.8 & 971.9 & 262.0 & 27.0 & n.s. \\
Mean & 447.5 & & & 659.8 & & & $*$
\end{tabular}

Note: ${ }^{*} P<0.05$; n.s.: not significant.

values of $D b$ and $\alpha$ found in soils for this land use, while the areas affected by trampling by cattle for several decades had significantly higher levels of resistance. For depths of 2.5 to $10.0 \mathrm{~cm}$, there were significant differences $(P<0.05)$. Starting at the $10.0 \mathrm{~cm}$ depth, the $R p$ of $\mathrm{PA}$ tended to resemble that of $\mathrm{BN}$, which is an indication that the 
compaction effect lies in the first centimeters of the soil, where the compacting loads are seen. The $R p$ values obtained in areas subjected to trampling by cattle in this research were much lower than those reported in the first $10 \mathrm{~cm}$ in Andisols of Chile (Dorner et al., 2012), with the same conditions. Furthermore, these results are comparable to those reported by Taboada \& Lavado (1988) for Andisols in Argentina for both trampled conditions and the control.

\section{Conclusion}

In soils of the headwaters in the Central Andes of Colombia, where natural forests are converted into cattle pastures, there were significant levels of compaction. The variation in the soil physical parameters used as indicators of the degree of compaction in pastures with respect to the reference values in natural forest were: $53.7 \%$ reduction in bulk density, $11.0 \%$ decrease in total porosity, approximate $0.8 \mathrm{~m}^{3} / \mathrm{m}^{3}$ decrease in moisture retention, and increased resistance to penetration the first $7.5 \mathrm{~cm}$ of the top soil from 275.2 to $527.2 \mathrm{kPa}$.

The decrease in porosity was widespread in all of the pore sizes, so that the proportion of macro, meso and micropores remained virtually unchanged in the compacted soils, as compared to those of the soils in the undisturbed natural forests.

Because of the high rainfall and uniform distribution throughout the year and the well-known high capacity for water retention in Andisols, the moisture content of these soils was usually high, close to the field capacity, favoring susceptibility to compaction, as caused by the frequent trampling of cattle in this case.

While there were significant levels of compaction in the soils subjected to trampling by cattle when compared to the reference values of the soils in the natural forest, the bulk density, porosity and penetration resistance remained within the normal ranges that are widely reported for Andisols.

From the above, it follows that the headwaters where land uses that implies compaction predominate, will suffer an accelerated causation for the generation of surface and subsurface runoff, limitations for water infiltration, less water recharge in the soils and low base flows, all of which will be reflected in a hydrological response of the greater watersheds.

\section{References}

Alaoui, A., Lipiec, J., \& Gerke, H. H. (2011). A Review of the Changes in the Soil Pore System Due to Soil Deformation: A Hydrodynamic Perspective. Soil \& Tillage Research, 115-116, 1-15. http://dx.doi.org/10.1016/j.still.2011.06.002

Alegre, J., \& Lara, P. (1991). Efecto de los animales en pastoreo sobre las propiedades físicas de suelos de la región tropical húmeda del Perú. Pasturas Tropicales, 13, 18-23.

Chaichi, M., Saravi, M., \& Malekin, A. (2005). Effects of Livestock Trampling on Soil Physical Properties and Vegetation Cover (Case Study: Lar Rangeland, Iran). International Journal of Agriculture \& Biology, 7, 904-908.

Dorner, J., Dec, D., Feest, E., Vásquez, N., \& Díaz, M. (2012). Dynamics of Soil Structure and Pore Functions of a Volcanic Ash Soil under Tillage. Soil \& Tillage Research, 125, 52-60.

http://dx.doi.org/10.1016/j.still.2012.05.019 
Gómez, K. (2011). Incidencia de la compactación ocasionada por el tractor en las propiedades físicas en un Andisol (104 p). Tesis Magister en Ingeniería Agrícola, Sede Bogotá: Universidad Nacional de Colombia, Facultad de Ingeniería.

Hamza, M. A., \& Anderson, W. K. (2005). Soil Compaction in Cropping Systems. A Review of the Nature, Causes and Possible Solutions. Soil \& Tillage Research, 82, 121-145.

http://dx.doi.org/10.1016/j.still.2004.08.009

Herbin, T., Hennessy, D., Richards, K. G., Piwowarczyk, A., Murphy, J.J., \&d Holden, N. M. (2011). The effects of dairy cow weight on selected soil physical properties indicative of compaction. Soil Use and Management, 27, 36-44.

http://dx.doi.org/10.1111/j.1475-2743.2010.00309.x

Hincapié, E. (2011). Estudio y Modelación del Movimiento del Agua en Suelos Volcánicos de Ladera (228 p). Tesis Doctoral, Sede Palmira: Universidad Nacional de Colombia.

Jiménez, C., Rosas, G., \& Falla, R. (2012). Efecto de la ganadería en las propiedades físicas del suelo de lomerío en el Centro de Investigaciones Amazónicas Macagual. Ingenierías \& Amazonia, 5, 42-50.

Leij, F. J., Ghezzehei, T., \& Or, D. (2002). Modeling the Dynamics of the Pore-Size Distribution. Soil \& Tillage Research, 64, 61-78. http://dx.doi.org/10.1016/S0167-1987(01)00257-4

Nanzyo, M. (2002). Unique Properties of Ash Volcanic Soils. Global Environmental Research, 6, 99-112.

Pinzón, A., \& Amézquita, E. (1991). Compactación de suelos por el pisoteo de animales en pastoreo en el piedemonte amazónico de Colombia. PasturasTropicales, 13, 21-26.

Reichardt, K., \& Timm, L. C. (2004). Solo, Planta e Atmosfera. Conceitos, Processos e Aplicações (478 p). São Paulo: Editora Manole.

Seki, K. (2007). SWRC Fit-A Nonlinear Fitting Program with a Water Retention Curve for Soils Having Unimodal and Bimodal Pore Structure. Hydrology and Earth Systems. Science Discussions, 4, 407-437.

Shoji, S., Nanzyo, M., \& Dahlgren, R. A. (1993). Volcanic Ash Soils: Genesis, Properties and Utilization. Developments in Soil Science 21 (288 p). Amsterdam: Elsevier.

SSS (Soil Science Society of America) (2008). Glossary of Soil Sciences Terms (88 p). United States of America.

Taboada, M. A., \& Lavado, R. S. (1988). Grazing Effects of the Bulk Density in a Natraquoll of the Flooding Pampa of Argentina. Journal of Range Management, 41, 500-503. http://dx.doi.org/10.2307/3899526

Tobón, C., Bruijnzeel, L. A., Fruman, K. F. A., \& Calvo-Alvarado, J. C. (2010). Changes in Soil Physical Properties after Conversion of Tropical Montane Cloud Forest to Pasture in Northern Costa Rica. In L. A. Bruijnzeel, F. N. Scatena, \& L. S. Hamilton (Eds.), Tropical Montane Cloud Forests: Science for Conservation and Management (pp. 502-515). Cambridge: Cambridge University Press.

Van Genuchten, M. (1980). A Closed-Form Equation for Predict in the Hydraulic Conductivity of Unsaturated Soils. Soil Science Society of American Journal, 44, 892-898.

http://dx.doi.org/10.2136/sssaj1980.03615995004400050002x

Van Genuchten, M., Leij, F., \& Yates, S. (1991). The RETC Code for Quantifying the Hydraulic Functions of Unsaturated Soils (93 p). Robert S. Kerr Environmental Research Laboratory, Office of Research and Development US Environmental Protection Agency, IAG-DW12933934.

Vaz, C. M. P., Manieri, J. M., De Maria, I., \& van Genuchten, M. (2013). Scaling the Dependency of Soil Penetration Resistance on Water Content and Bulk Density of Different Soils. Soil Science Society of America Journal, 77, 1488-1495. http://dx.doi.org/10.2136/sssaj2013.01.0016 
Vzzotto, V. R., Marchezan, E., \& Sagabinazzi, T. (2000). Efeito do pisoteio bovino em algumas propriedades físicas do solo de várzea. Ciência Rural, 30, 965-969. http://dx.doi.org/10.1590/S0103-84782000000600007

Wolkowski, R., \& Lowery, B. (2008). Soil Compaction: Causes, Concerns and Cures (8 p). University of Wisconsin Extension A3367.

Submit or recommend next manuscript to SCIRP and we will provide best service for you:

Accepting pre-submission inquiries through Email, Facebook, LinkedIn, Twitter, etc. A wide selection of journals (inclusive of 9 subjects, more than 200 journals)

Providing 24-hour high-quality service

User-friendly online submission system

Fair and swift peer-review system

Efficient typesetting and proofreading procedure

Display of the result of downloads and visits, as well as the number of cited articles Maximum dissemination of your research work

Submit your manuscript at: http://papersubmission.scirp.org/ 